CLINICAL STUDY

\title{
Intellectual outcome at 12 years of age in congenital hypothyroidism
}

\author{
Mariacarolina Salerno ${ }^{1}$, Roberto Militerni ${ }^{2}$, Salvatore Di Maio $^{1}$, Carmela Bravaccio ${ }^{2}$, Nicoletta Gasparini ${ }^{1}$ \\ and Alfred Tenore ${ }^{3}$ \\ ${ }^{1}$ Department of Paediatrics, University of Naples 'Federico II', ${ }^{2}$ Chair of Child Neuropsychiatry, Second University, Naples and \\ ${ }^{3}$ Department of Pediatrics (DPMSC) University of Udine, Italy \\ (Correspondence should be addressed to M Salerno, Department of Paediatrics, University of Naples 'Federico II', Via S Pansini 5 , \\ I-80131 Naples, Italy)
}

\begin{abstract}
Background: The intellectual outcome in children with congenital hypothyroidism detected by neonatal screening is generally good; however, subtle neurological dysfunctions, subnormal IQ, or both, have been reported.

Objective: To evaluate the intellectual outcome in 12-year-old patients with congenital hypothyroidism, detected by neonatal screening, in an attempt to identify factors that may affect intellectual development.

Methods: The intelligence quotient (IQ) of 40 children with congenital hypothyroidism was evaluated at 12 years of age, using the Wechsler Intelligence Scale for Children - Revised, and compared with the IQ of 40 healthy siblings (control group).

Results: The mean IQ score $(88.4 \pm 13.1)$ was not significantly different from that of the control group (93.4 \pm 10.7$)$. Thirteen patients showed subnormal IQ score $(72.4 \pm 4.9)$ compared with their siblings $(86.7 \pm 9.6 ; P<0.0001)$ and with the other patients $(96.1 \pm 9.6 ; P<0.0001)$. The low IQ score was associated with lower serum concentrations of thyroxine at diagnosis, poor treatment compliance during follow-up and lower familial IQ. Interviews with parents of children with congenital hypothyroidism revealed that a refusal to acknowledge the disease was linked to poor attention to the child's emotional life and to poor treatment compliance in some cases (11\%).

Conclusion: Even though the mean IQ score in patients with congenital hypothyroidism falls within normal for the control population, low IQ scores may be present in patients with severe hypothyroidism, inadequate compliance to replacement therapy during follow-up and poor parental pedagogic attitude.
\end{abstract}

European Journal of Endocrinology 141 105-110

Part of this study was presented at the 5th Joint Meeting of the European Society for Pediatric Endocrinology (ESPE) and the Lawson Wilkins Pediatric Endocrine Society (LWPES) held in Stockholm, Sweden, 22-26 June 1997.

\section{Introduction}

The introduction of systematic neonatal screening for congenital hypothyroidism has resulted in early detection and successful treatment of affected children. Although neurological development is generally good in treated children (1-3), subtle motor and cognitive deficits and impaired intellectual outcome have been detected in some cases (4-10). These slight neurological deficits are related to the severity of congenital hypothyroidism at diagnosis as assessed by serum thyroxine $\left(\mathrm{T}_{4}\right)$ concentrations or bone age $(4,6-9$, $11)$, to the age at diagnosis (12), and to the dose of
L-thyroxine replacement therapy (13-16). The results of two studies that monitored patients during adolescence are conflicting: the New England Congenital Hypothyroidism Collaborative study (3) did not find differences in cognitive or in school performance among patients, their siblings or classmates in 14 years of follow-up, whereas Glorieux et al. (6) detected lower intelligence quotient (IQ) scores in 12-year-old children whose hypothyroidism was more severe at diagnosis.

We evaluated the intellectual development in our early adolescent patients in an attempt to identify factors that may be of prognostic value in influencing intellectual outcome. 


\section{Patients and methods}

Of the 64 children referred to our Department of Paediatrics between 1982 and 1985 by a regional screening programme for congenital hypothyroidism, nine were lost to follow-up, and the parents of 15 refused consent for intellectual evaluation. The remaining 40 patients (30 female) were followed longitudinally from the time of diagnosis until they reached a mean age of 12 years. Informed consent was obtained from the parents of these 40 patients.

The diagnosis of congenital hypothyroidism was confirmed by serum thyroid function tests. Skeletal development, expressed in fetal weeks, was evaluated (always by the same observer) by comparing knee and foot radiographs with the standards for different ages according to Kuhns \& Finnstrom (17). Treatment was started at a mean chronological age of $28.2 \pm 10.8$ days (range 12-53 days).

The aetiology of congenital hypothyroidism was established by ${ }^{99} \mathrm{~m}$ Tc- pertechnetate thyroid scans at the time of diagnosis or at 3 years of age and after L-thyroxine therapy had been withdrawn for 6 weeks. Twenty-four children had ectopic glands, eight had dyshormonogenesis and eight had thyroid aplasia.

Immediately after diagnosis, L-thyroxine therapy was started at a dose of $25 \mu \mathrm{g}(6.8 \pm 1.8 \mu \mathrm{g} / \mathrm{kg}$ body weight) given orally once a day. Table 1 shows the main clinical findings at diagnosis of the 40 patients studied compared with those of the 24 patients lost to follow-up, and demonstrates that patients lost were not different and therefore did not constitute a bias in the selection of the population studied.

Children were evaluated at 3, 6, 9 and 12 months of life during the first year of treatment, then every 3 or 6 months until they reached the 3rd year of age, and annually thereafter. Dosage was adjusted according to clinical and biochemical data in order to keep serum $\mathrm{T}_{4}$ concentrations within the upper normal range and serum thyroid stimulating hormone (TSH) within the normal range. The IQ was evaluated at a mean age of 12.25 \pm 0.9 years (range 11-14 years) using the Wechsler Intelligence Scale for Children - Revised (WISC-R) (18), which yields a full-scale score, a verbal score, a performance score, and scores on 10 subtests.

Table 1 Main clinical findings at the beginning of treatment in the 40 patients in the study, compared with those of the 24 patients lost to follow-up.

\begin{tabular}{|c|c|c|c|}
\hline & $\begin{array}{c}\text { Patients in } \\
\text { the study } \\
(n=40)\end{array}$ & $\begin{array}{l}\text { Patients lost to } \\
\text { follow-up } \\
(n=24)\end{array}$ & $\boldsymbol{P}$ \\
\hline Chronological age (days) & $28 \pm 10$ & $31 \pm 10$ & NS \\
\hline Bone age (weeks) & $36 \pm 4$ & $35 \pm 3$ & NS \\
\hline Serum $\mathrm{T}_{4}(\mathrm{nmol} / \mathrm{l})$ & $41.2 \pm 32$ & $41.0 \pm 37$ & NS \\
\hline Serum TSH $(\mu \mathrm{U} / \mathrm{ml})$ & $670 \pm 640$ & $530 \pm 334$ & NS \\
\hline $\mathrm{L}-\mathrm{T}_{4}(\mu \mathrm{g} / \mathrm{kg}$ per day $)$ & $6.8 \pm 1.8$ & $6.9 \pm 1.8$ & NS \\
\hline
\end{tabular}

The test was administered by the same psychologist, to minimise subjective interpretation of the test. All patients had normal thyroid function studies when the test was administered (serum $\mathrm{T}_{4}>103 \mathrm{nmol} / \mathrm{l}$; serum $\mathrm{TSH}<5 \mu \mathrm{U} / \mathrm{ml})$. The IQ scores were compared with the results of developmental and intellectual evaluation performed at 2 years (Brunet-Lezine test) and at 7 years of age (Stanford-Binet) respectively (9).

To counter the effect of parental education and socioeconomic status, the control group consisted of 40 healthy siblings with a mean chronological age of 12.25 years (range 7.25-16.25 years), who were assessed by the same psychologist using the same test. All parents underwent a semistructured interview to evaluate the quality of life of the family and familial relationships. A non-directive technique was used that encourages the informant to talk about the issues they believe to be important, so that the interview serves as a standard stimulus for eliciting emotions and attitudes, in addition to being a means of eliciting information.

Statistical analysis was performed by unpaired Student's $t$-test and linear regression analysis. The results are expressed as means \pm S.D.

\section{Results}

The IQs of the 40 children with congenital hypothyroidism, evaluated when the children were 12 years

Table 2 Comparison of the mean ( \pm S.D.) values for WISC-R IQ scores at 12 years of age between 40 patients with congenital hypothyroidism $(\mathrm{CH})$ and their siblings.

\begin{tabular}{lccl}
\hline WISC-R & $\begin{array}{c}\text { Patients with CH } \\
(n=40)\end{array}$ & $\begin{array}{c}\text { Siblings } \\
(n=40)\end{array}$ & $\boldsymbol{P}$ \\
\hline Verbal IQ & $93.2 \pm 15.2$ & $93.4 \pm 10.7$ & NS \\
Performance IQ & $84.9 \pm 13.1$ & $91.7 \pm 10.5$ & $<0.04$ \\
Full-scale IQ & $88.4 \pm 14.0$ & $91.8 \pm 10.5$ & $\mathrm{NS}$ \\
\hline
\end{tabular}

Table 3 Comparison of the mean ( \pm S.D.) values for the 10 WISC-R IQ subtest at 12 years of age between 40 patients with congenital hypothyroidism $(\mathrm{CH})$ and their siblings.

\begin{tabular}{lrrl}
\hline WISC-R subtest & $\begin{array}{r}\text { Patients with CH } \\
(n=40)\end{array}$ & $\begin{array}{r}\text { Siblings } \\
(n=40)\end{array}$ & $\boldsymbol{P}$ \\
\hline Information & $8.0 \pm 2.6$ & $7.8 \pm 2.5$ & $\mathrm{NS}$ \\
Similarities & $10.1 \pm 3.2$ & $8.1 \pm 1.9$ & $\mathrm{NS}$ \\
Arithmetic & $9.5 \pm 2.7$ & $9.2 \pm 1.8$ & $\mathrm{NS}$ \\
Vocabulary & $9.7 \pm 3.8$ & $10.1 \pm 2.6$ & $\mathrm{NS}$ \\
Comprehension & $7.2 \pm 2.8$ & $9.6 \pm 3.5$ & 0.001 \\
Picture completion & $7.5 \pm 2.3$ & $8.8 \pm 2.1$ & 0.01 \\
Picture arrangement & $8.7 \pm 3.4$ & $9.3 \pm 2.1$ & $\mathrm{NS}$ \\
Block design & $8.6 \pm 2.5$ & $10.3 \pm 2.2$ & 0.002 \\
Object assembly & $7.8 \pm 2.2$ & $9.0 \pm 2.9$ & 0.04 \\
Coding & $6.4 \pm 3.7$ & $6.6 \pm 2.6$ & $\mathrm{NS}$ \\
\hline
\end{tabular}


Table 4 Comparison of the mean ( \pm S.D.) values for WISC-R verbal, performance and full-scale IQ scores at 12 years of age in 40 patients with congenital hypothyroidism, divided on the basis of the aetiology.

\begin{tabular}{lccc}
\hline WISC-R & $\begin{array}{c}\text { Agenesis group } \\
(n=8)\end{array}$ & $\begin{array}{c}\text { Ectopic gland/ } \\
\text { dyshormonogenesis } \\
\text { group }(n=32)\end{array}$ & $\boldsymbol{P}$ \\
\hline Verbal IQ & $83.6 \pm 12.7$ & $95.6 \pm 15.0$ & $=0.04$ \\
Performance IQ & $76.4 \pm 6.8$ & $87.0 \pm 13.5$ & $<0.04$ \\
Full-scale IQ & $78.5 \pm 9.1$ & $90.8 \pm 14.0$ & $=0.02$ \\
\hline
\end{tabular}

Table 5 Comparison of the mean ( \pm S.D.) values for WISC-R verbal, performance and full-scale IQ scores at 12 years of age in patients with congenital hypothyroidism and their siblings. The IQ scores in the patients were separated into normal $(\geqslant 80)$ or subnormal $(<80)$ groups.

\begin{tabular}{lcccc}
\hline WISC-R & $\begin{array}{c}\text { Patients with } \\
\mathbf{I Q} \geqslant \mathbf{8 0} \\
(n=27)\end{array}$ & $\begin{array}{c}\text { Siblings } \\
(n=27)\end{array}$ & $\begin{array}{c}\text { Patients with } \\
\mathbf{I Q}<\mathbf{8 0} \\
(n=13)\end{array}$ & $\begin{array}{c}\text { Siblings } \\
(n=13)\end{array}$ \\
\hline Verbal IQ & $101.6 \pm 10.2$ & $95.4 \pm 11.5$ & $75.8 \pm 6.3^{*}$ & $89.1 \pm 9.5$ \\
Performance IQ & $90.8 \pm 11.3$ & $94.0 \pm 8.7$ & $72.6 \pm 6.3^{*}$ & $86.8 \pm 10.6$ \\
Full-scale IQ & $96.1 \pm 9.6$ & $94.3 \pm 0.2$ & $72.4 \pm 4.9^{*}$ & $86.7 \pm 9.6$ \\
\hline
\end{tabular}

${ }^{*} P<0.0001$ with respect to both siblings and patients with $\mathrm{IQ} \geqslant 80$.

old, were within normal range (Table 2). The patients' mean full-scale score was significantly correlated to that of the siblings $(r=0.47, P=0.002)$. The mean verbal score was also similar in the two groups, even though there was a significant difference in comprehension (Table 3). In contrast, patients had a performance deficit of seven IQ points with respect to siblings $(P<0.04)$. The subtests mainly affected (Table 3) were picture completion, block design and assembly of objects.

The mean full-scale score at 12 years of age was significantly correlated with the full-scale score of the same patient at 2 years $(96.3 \pm 9.6 ; r=0.40$, $P=0.015)$ and at 7 years of age $(96.4 \pm 8.5 ; r=0.63$, $P=0.001$ ). It was also correlated with serum $\mathrm{T}_{4}$ concentrations at diagnosis $(r=0.50 ; P=0.001)$.

In 22 of 24 patients lost to follow-up, IQ evaluated at 7 years of age $(92.2 \pm 10)$ did not significantly differ from that of the 40 patients at the same age (96.4 \pm 8.5; not significant).

As expected, given the relationship between serum $\mathrm{T}_{4}$ and IQ scores, our thyroid agenesis group had significantly worse verbal, performance and full-scale scores compared with the ectopic and dyshormonogenesis groups (Table 4), and with siblings (verbal score 94.6 \pm 12 , NS; performance score $92.1 \pm 6.5$, $P<0.0001$; full-scale score $92.9 \pm 10.3, P<0.02)$. We divided the patients with congenital hypothyroidism into two groups according to individual full-scale scores and inter-sibling comparison (Table 5): group A $(n=27)$ consisted of patients with a normal full-scale score $(\geqslant 80)$, which was comparable to their siblings' score; and group B $(n=13)$ consisted of patients with subnormal IQ $(<80)$, which was significantly lower with respect to their siblings' score. Group B had a lower full-scale score at 2 years $(87.6 \pm 8.3)$, and 7 years of age $(87 \pm 8.6)$ with respect to group A $(99.7 \pm 7.9, P<0.0001$; and $100 \pm 5.0, P<0.0001)$.

Table 6 Comparison of hormonal assessment at the beginning of treatment and during the first year of follow-up in 27 patients with congenital hypothyroidism who had normal IQ scores at 12 years of age and in 13 patients with subnormal IQ scores.

\begin{tabular}{|c|c|c|c|}
\hline & $\begin{array}{c}\text { Patients with } \\
I \mathbf{Q} \geqslant 80 \\
(n=27)\end{array}$ & $\begin{array}{c}\text { Patients with } \\
\mathbf{I Q}<\mathbf{8 0} \\
(n=13)\end{array}$ & $P$ \\
\hline \multicolumn{4}{|l|}{ Diagnosis } \\
\hline Serum $\mathrm{T}_{4}(\mathrm{nmol} / \mathrm{l})$ & $51.5 \pm 33.5$ & $20.3 \pm 12.9$ & 0.003 \\
\hline Serum TSH $(\mu \mathrm{U} / \mathrm{ml})$ & $715 \pm 555$ & $575 \pm 801$ & NS \\
\hline Age (days) & $28.8 \pm 11.9$ & $26.9 \pm 8.4$ & NS \\
\hline Bone age (weeks) & $35.9 \pm 3.8$ & $35.4 \pm 5.1$ & NS \\
\hline $\mathrm{L}^{-\mathrm{T}_{4}}(\mu \mathrm{g} / \mathrm{kg}$ per day $)$ & $6.9 \pm 2.1$ & $6.5 \pm 0.8$ & NS \\
\hline \multicolumn{4}{|l|}{3 months of age } \\
\hline Serum $T_{4}(\mathrm{nmol} / \mathrm{l})$ & $155.0 \pm 42.2$ & $166.5 \pm 50.8$ & NS \\
\hline Serum TSH $(\mu \mathrm{U} / \mathrm{ml})$ & $25.9 \pm 32.3$ & $36.2 \pm 54.2$ & NS \\
\hline $\mathrm{L}-\mathrm{T}_{4}(\mu \mathrm{g} / \mathrm{kg}$ per day $)$ & $4.6 \pm 1.0$ & $4.5 \pm 0.7$ & NS \\
\hline \multicolumn{4}{|l|}{6 months of age } \\
\hline Serum $\mathrm{T}_{4}(\mathrm{nmol} / \mathrm{l})$ & $154.4 \pm 38.6$ & $167.3 \pm 38.0$ & NS \\
\hline Serum TSH $(\mu \mathrm{U} / \mathrm{ml})$ & $11.0 \pm 8.0$ & $8.4 \pm 5.0$ & NS \\
\hline $\mathrm{L}^{-\mathrm{T}_{4}}(\mu \mathrm{g} / \mathrm{kg}$ per day $)$ & $4.5 \pm 0.6$ & $4.7 \pm 0.7$ & NS \\
\hline \multicolumn{4}{|l|}{12 months of age } \\
\hline Serum $\mathrm{T}_{4}(\mathrm{nmol} / \mathrm{l})$ & $154.8 \pm 37.4$ & $163.4 \pm 26.8$ & NS \\
\hline Serum TSH $(\mu \mathrm{U} / \mathrm{ml})$ & $6.9 \pm 6.7$ & $4.3 \pm 5.3$ & NS \\
\hline $\mathrm{L}-\mathrm{T}_{4}(\mu \mathrm{g} / \mathrm{kg}$ per day $)$ & $4.4 \pm 0.9$ & $4.5 \pm 1.4$ & NS \\
\hline
\end{tabular}


Moreover the mean IQ in siblings of group A was higher than IQ in siblings of group B $(P<0.02)$.

The low full-scale score, in patients of group B, was associated with lower serum $\mathrm{T}_{4}$ concentrations at diagnosis (Table 6). Mean chronological age, bone age, initial L-thyroxine replacement therapy and hormonal assessment in the first year of life were similar in the two groups. The high frequency of increased serum TSH concentrations throughout the period of follow-up (Fig. 1a) in the group of patients with the lower IQ outcome, accompanied by normal serum $\mathrm{T}_{4}$ concentrations (Fig. $1 b$ ) after the age of 2 years, suggests a poor compliance with treatment.

The interviews with parents showed that the diagnosis of congenital disease, the perspective of endless treatment, and the need for continuous assessments were stressful events that had deleterious effects on parental well being. The ways in which the families coped with psychological distress was related to such personal and socioecological factors as personality traits, marital relationships, size of the family, whether the mother worked outside the home, and socioeconomic circumstances. We identified three educational-affective attitudes: (a) parents who could cope with the emotional distress and who were able to develop a satisfactory attitude toward rearing the child and toward the therapeutic programme (38\%); (b) parents whose anxiety resulted in overstimulation of the child and strict compliance with the therapeutic programme (51\%); and (c) parents in whom a refusal to acknowledge the disease was linked to poor attention to their child's emotional well being and to poor treatment compliance in terms of postponing or missing appointments $(11 \%)$. None of the parents acknowledged that therapy was not given regularly. The three types of parental profiles were distributed equally between the two groups of children - with and without subnormal IQ.

\section{Discussion}

Although the mean full-scale IQ score in our children with congenital hypothyroidism was within the normal range and similar to that of their siblings, significant differences were detected in verbal and performance scores. Interestingly, while the mean verbal score was normal compared with siblings, the performance score was significantly lower. Within the performance test, the items significantly affected were picture completion, block design, and object assembly, which are considered to have a particularly high spatial loading. According to a large body of evidence, a discrepancy between verbal score and performance score, and poor perceptual organisation as evaluated by the block design and object assembly items, are indicative of brain damage, even if minimal. The biological damage seems to be related to a greater severity or duration, or both, of hypothyroidism at diagnosis, and the group with subnormal IQ scores did indeed have more severe forms of hypothyroidism at diagnosis. This confirms the findings of studies (19) in which verbal, performance and full-scale scores were lower in patients with congenital hypothyroidism than in well-defined control groups, although the differences were not always significant.

Despite evidence that maternal $\mathrm{T}_{4}$ contributes substantially to fetal thyroxine in the later weeks of pregnancy (20), it appears that maternal transfer is insufficient for fetal requirements in cases of severe hypothyroidism $(11,19)$. The severity of hypothyroidism in the prenatal and perinatal periods may have important long-term effects on brain development, function, or both. In fact, suboptimal mental outcome was present at 2, 7 and 12 years of age in our patients with a severe form of the disorder. Conversely, serum $\mathrm{T}_{4}$ concentrations at diagnosis are in some cases strictly related to the age at diagnosis; in patients with agenesis, the later the age at the beginning of treatment the lower will the serum $\mathrm{T}_{4}$ concentrations be and, consequently, the intellectual outcome.

A higher starting dose of L-thyroxine - for example $10-15 \mu \mathrm{g} / \mathrm{kg}$ per day - has been proposed to allow hypothyroid children to rapidly achieve optimal levels of circulating $\mathrm{T}_{4}$ and therefore minimise the brain damage that results from prolonged hypothyroidism (13-15). Preliminary results are encouraging (16), and suggest that a higher initial dose of L-thyroxine would probably have erased the difference in the intellectual outcome in our two groups of patients.

After 2 years of age, the greater frequency of increased serum TSH associated with normal serum $\mathrm{T}_{4}$ concentrations in patients with lower IQ indicated that poor compliance to treatment might be another factor affecting intellectual outcome. This is in line with the New England Congenital Hypothyroidism Collaborative report of normal IQ scores up to the age of 14 years except in instances of poor treatment compliance (3). We agree with the New England study that yearly controls after 3 years of age are insufficient, and that more frequent surveillance of the patient's hormonal status may help to establish when patients, parents, or both, fail to follow the treatment schedule.

An additional factor influencing neuropsychological outcome might be parental pedagogic attitude. It is difficult to establish the significance of the information gathered from the parents' interviews. The three types of parental profiles were distributed equally between the two groups of children - those with and those without mental retardation. The fact that 'overstimulation' and 'control' were the most frequent parental attitudes could explain why the patients with normal full-scale score performed better than their siblings on the verbal test (Table 5). Moreover, the significant relationship between the IQ of the patients and that of their siblings and the higher IQ score in 

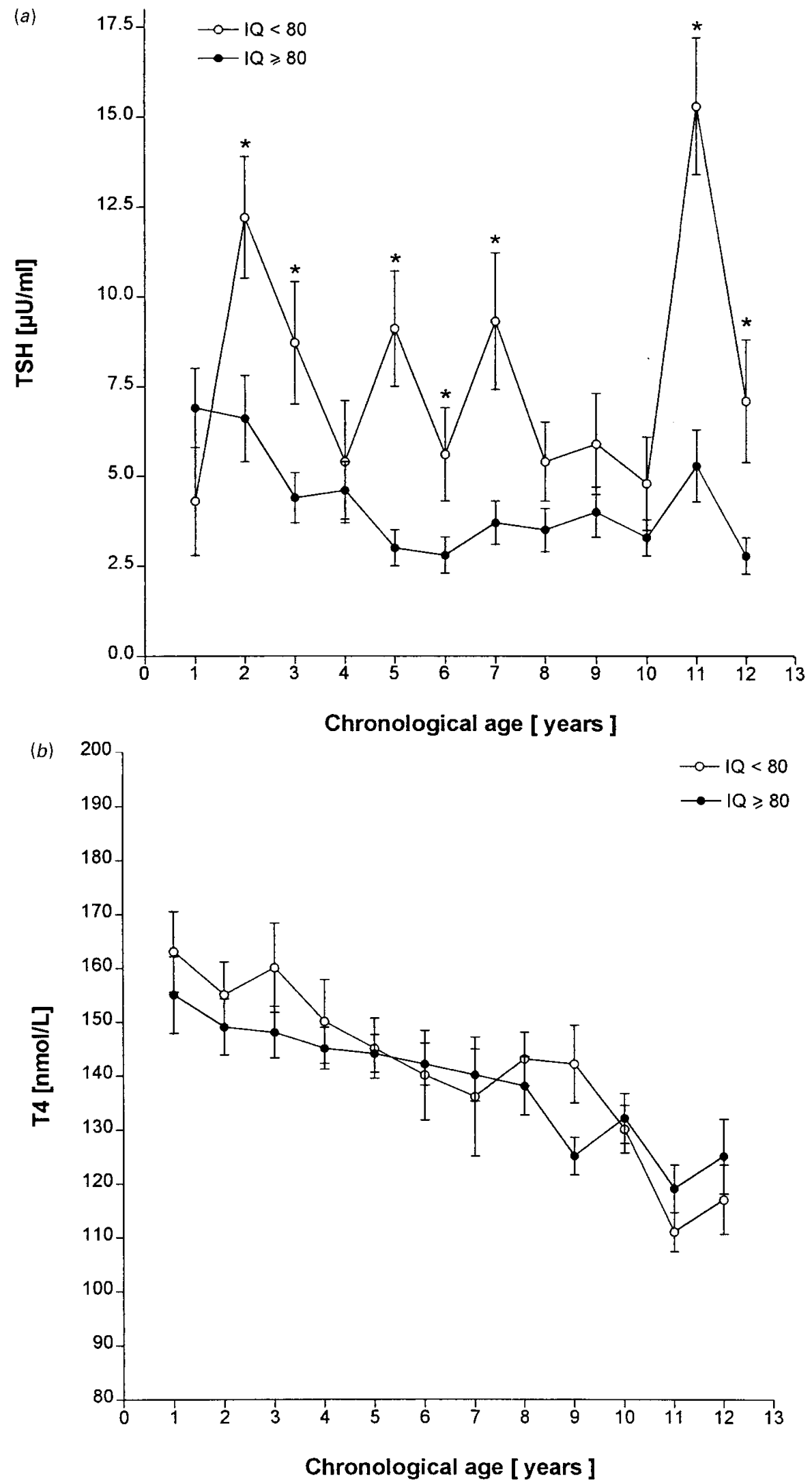

Figure 1 (a) Mean ( \pm S.E.M.) serum TSH concentration during the follow-up period in patients with $I Q<80(O)$ was significantly greater than that of patients with $I Q \geqslant 80(\bullet)$ at $2,3,5,6,7,11$ and 12 years of age $\left({ }^{\star} P<0.005\right)$. (b) In contrast, serum $\mathrm{T}_{4}$ concentrations were similar in both groups throughout the period of follow-up (NS). 
siblings of patients with better intellectual outcome suggest that familial IQ is another factor affecting the mental outcome of our patients.

Besides intellectual aspects, the neuropsychiatric assessment revealed emotional disorders related to problems of self-confidence in almost all patients. We are still analysing these findings, but our preliminary results suggest that a therapeutic programme, even though focused on physical issues, must take into account the relationships between parents, and between parents and child, and the functioning of the family unit as a whole.

In conclusion, our findings indicate that the intellectual outcome at 12 years of age in patients with congenital hypothyroidism is generally good. However, several factors such as the severity of congenital hypothyroidism at diagnosis, poor compliance to replacement therapy during follow-up, low familial IQ and poor parental pedagogic attitude might affect the intellectual outcome. Therefore, starting the treatment as early as possible, with higher doses of $\mathrm{L}_{-} \mathrm{T}_{4}$, together with strict surveillance of the therapy and psychological support to the parents will probably assure a normal outcome in all patients with congenital hypothyroidism.

\section{References}

1 Toublanc JE, Rives S, Acosta A \& Chicaud J. Le développement psychomoteur et intellectuel chez 52 enfants atteints d'hypothyroidie congénitale dépistée à la naissance. Archives Francaises de Pediatrie 199047 191-195.

2 Ilicki A \& Larsson A. Psychological development at 7 years of age in children with congenital hypothyroidism. Acta Paediatrica Scandinavica 199180 199-204.

3 New England Congenital Hypothyroidism Collaborative. Correlation of cognitive test scores and adequacy of treatment in adolescents with congenital hypothyroidism. Journal of Pediatrics 1994124 383-387.

4 Rovet J, Ehrlich R \& Sorbara D. Intellectual outcome in children with fetal hypothyroidism. Journal of Pediatrics $1987110700-704$.

5 Fuggle PW, Grant DB, Smith I \& Murphy G. Intelligence, motor skills and behaviour at 5 years in early-treated congenital hypothyroidism. European Journal of Pediatrics 1991150 570-574.

6 Glorieux J, Dussault J \& Van Vliet G. Intellectual development at age 12 years of children with congenital hypothyroidism diagnosed by neonatal screening. Journal of Pediatrics 1992121 581-584.

7 Kooistra L, Laane C, Vulsna T, Schellekens JM, Van der Meere JJ \& Kalverboer F. Motor and cognitive development in children with congenital hypothyroidism: a long-term evaluation of the effects of neonatal treatment. Journal of Pediatrics 1994124 903-909.

8 Simons WF, Fuggle PW, Grant DB \& Smith I. Intellectual development at 10 years in early treated congenital hypothyroidism. Archives of Disease in Childhood 199471 232-234.

9 Salerno M, Di Maio S, Militerni R, Argenziano A, Valerio G \& Tenore A. Prognostic factors in the intellectual development at 7 years of age in children with congenital hypothyroidism. Journal of Endocrinological Investigation 199518 774-779.

10 Kooistra L, Van der Meere JJ, Vulsna T \& Kalverboer F. Sustained attention problems in children with early treated congenital hypothyroidism. Acta Paediatrica 199685 425-429.

11 Tillotson SL, Fuggle PW, Smith I, Ades AE \& Grant DB. Relation between biochemical severity and intelligence in early treated congenital hypothyroidism: a threshold effect. British Medical Journal 1994309 440-445.

12 Illig R, Largo RH, Qiun Q, Torresani T, Rocchiccioli P \& Larsson A. Mental development in congenital hypothyroidism after neonatal screening. Archives of Disease in Childhood 198762 405-411.

13 Fisher DA \& Foley BL. Early treatment of congenital hypothyroidism. Pediatrics 198983 785-789.

14 Heyerdahl S, Kase BF \& Lie SO. Intellectual development in children with congenital hypothyroidism in relation to recommended thyroxine treatment. Journal of Pediatrics 1991118 850-857.

15 Rovet JF \& Ehrlich RM. Long-term effects of L-thyroxine therapy for congenital hypothyroidism. Journal of Pediatrics 1995126 380-386.

16 Dubuis JM, Glorieux J, Richer F, Deal CL, Dussault JH \& Van Vliet G. Outcome of severe congenital hypothyroidism: closing the developmental gap with early high dose levothyroxine treatment. Journal of Clinical Endocrinology and Metabolism 1996 $81222-227$.

17 Kuhns LR \& Finnstrom O. New standards of ossification of the newborn. Radiology 1976119 655-660.

18 Wechsler D. Manual for the Wechsler Intelligence Scale for Children Revised. New York: Psychological Corporation 1974.

19 Derksen-Lubsen G \& Verkerk PH. Neuropsychologic development in early treated congenital hypothyroidism: analysis of literature data. Pediatric Research $199639561-566$.

20 Vulsma T, Gons MH \& de Vijder JJM. Maternal-fetal transfer of thyroxine in congenital hypothyroidism due to a total organification defect or thyroid agenesis. New England Journal of Medicine 1989321 13-16.

Received 30 July 1998

Accepted 8 March 1999 